\title{
Ydre mission som dansk kulturhistorie
}

\author{
Lektor emeritus, cand.theol. et dr.theol. h.c. \\ Hans Raun Iversen
}

En forskningsoversigt i anledning af Daniel Henschen: Da danskerne ville omvende verden. Historien om missionsbevagelsen. København: Gads Forlag 2019. 281 s. Kr. 349,95.

\begin{abstract}
In his new book, Daniel Henschen studies the foreign mission movement in Denmark as a case of an "empathic globalization" before modern globalization began to be developed at full scale from around 1960. The book is innovative in viewing the mission movement in Denmark as an integrated part of contemporary culture, contributing to the general cultural and political development in its time. At the same time, Henschen develops a new track in mission studies.
\end{abstract}

Key words: foreign missions - mission in local culture - perspectives in mission studies.

\section{Strategier i studiet af ydre mission}

Resultatet af akademiske studier afhænger af det perspektiv, der anlægges. Verdens første universitetsstilling med fokus på ydre mission var Gustav Warnecks professorat i missionsvidenskab i Halle fra 1896. Lorenz Bergmann fulgte trop i et lektorat i missionshistorie i København fra 1918. Fokus var begge steder på de af kirkerne uafhængige missionsselskabers virksomhed og særligt de udsendte missionærers arbejde i kolonierne. Her var der et ganske stort uudforsket område at studere. En omkostning ved dette fokus var, at missionsstudierne kom til at bidrage til den ensidige forståelse af mission som europæiske missionærers indsats blandt mennesker under hedenske himmelstrøg. Fra 1960'erne fremkom der en stærk reaktion mod denne eurocentriske missionshistorie. Den var især drevet af unge forskere fra missionsområderne, der fremhævede det lokale initiativ og den 
lokale baggrund som afgørende for kristendommens udtryksformer og udbredelse i deres lande. ${ }^{1}$

Med kolonitidens afslutning efter anden verdenskrig stod det klart, at missions(selskabs)historie var utilstrækkelig, når man ville forstå den kristne mission. Forskningen var på vej ind i en blindgyde. Holger Bernt Hansen foreslog i 1974 at afskaffe betegnelsen missionshistorie og i stedet at se samlet på kirkernes og de kristnes virke til kristendommens fremme med en universelt anlagt kirkehistorie. ${ }^{2} \mathrm{Et}$ ambitiøst bidrag til at drage den fulde konsekvens af dette synspunkt foreligger med trebindsværket om den globale kristendoms historie, som Jens Holger Schjørring har været primus motor for. ${ }^{3}$ Et andet eksempel er Harald Nielsens store værk om Det Danske Missionsselskabs (DMS) snart 200 årige historie, hvor det bliver klart, at det ikke blot er tale om en fælles baggrund i det kirkeligt-kulturelle landskab i Danmark, men også om at en lang række aktører i missionsselskabshistorien er de samme som i kirkelivet i øvrigt. ${ }^{4}$

Det slår imidlertid ikke til at integrere missionshistorien i kirkehistorien, selv om det er nyttigt for begge discipliner. Der må også drives specialiserede studier i, hvad det er, der sker i menneskers liv både ude og hjemme, når de inddrages i kristen mission. Hvor den kristne missions budskab sætter sig igennem, transformeres verdensbilledet og kristendomsforståelsen både hos afsender og modtager, sådan som hovedtesen lyder i David Bosch' Transforming Mission. ${ }^{5}$ Det kan man få syn for, når man inddrager antropologiske synsvinkler i studiet af mission som udtryk for et kulturmøde. Den bestræbelse har en lang tradition bag sig, omfattende bl.a. etnologisk anlagte kulturstudier gennemført af antropologisk tænkende missionærer (se fx Henschen 2019, 80 og 180). Markante nutidige bidrag til området er Niels Kastfelts studier af især nigeriansk kristendom gennem snart 45 år. $^{6}$

1. Se fx David Barrett (ed.), African Initiatives in Religion: 21 Studies from Eastern and Central Africa (Nairobi: East African Publishing House 1971).

2. Holger Bernt Hansen, "Fra missionshistorie til universel kirkehistorie", Dansk Teologisk Tidsskrift 37 (1974), 280-307.

3. Jens Holger Schjørring m.fl., Geschichte des globalen Christentums. Religionen des Menschen Band 32, 33 og 34 (Stuttgart: Kohlhammer Verlag 2017).

4. Harald Nielsen, Det Danske Missionsselskabs historie 1821-1985. Bind I: Frygt ikke! Troe ikkun! Bind II: Mission i en forandret verden (Hellerup: Danmission 2019).

5. David Bosch, Transforming Mission. Paradigm Shifts in Theology of Mission (New York: Orbis Books 1992). Denne magistrale bog er på én gang en sammenhængende kirke- og missionshistorie og en systematisk teologisk missionsteologi.

6. Se fx Niels Kastfelt, "Kristendom i grænseland. Kirkehistoriske perspektiver på et afrikansk kulturmøde", Dansk Teologisk Tidsskrift 76 (2013), 2-20; "Grænsegængerne: Missionærer, kulturformidling og den moderne verden”, Gransegangere: Missionarer, kultur og den moderne verden, red. Mogens Mogensen (Frederiksberg: Dansk Missionsråd 2013) 8-27. 


\section{Ydre mission i kulturhistorisk belysning}

Hvad skete der i Danmark, når mennesker her lod sig engagere i missionsbevægelsen? Var der kun tale om, at nogle omvendelseskristne samlede midler sammen, så deres fromme kristendom kunne blive indlemmet $\mathrm{i}$ den civilisatoriske kulturpakke, som kolonisatorerne havde sat sig for at plante i de fremmede lande? Belysningen af det spørgsmål har hidtil været beskeden i dansk kontekst. ${ }^{7}$ Det er der nu rådet bod på med udgivelsen af kulturhistorikeren Daniel Henschens bog "Da danskerne ville omvende verden", der introducerer missionsbevægelsen som et stykke dansk kulturhistorie. Henschen tager fra begyndelsen læseren med ind i missionsbevægelsens hjerte:

Den 10. december 1925 var en råkold dag i Viborg med temperaturer lige omkring frysepunktet. I aviserne optog julehandlen det meste sammen med arbejdsmarkedsforhandlinger og afgørelsen i en sag om et brutalt barnemord i København. Alt sammen må have virket meget langt væk for den gruppe mænd, der sad i bispegården i Domkirkestræde og lyttede intenst til et foredrag om det varme Sydindien. Det var nemlig ikke det ukendte og fremmedartede, der optog dem - nej, de vandrede ad velkendte stier, og ved et bestemt indisk navn brød de ellers så alvorlige mænd ud i jubel (Henschen 2019, 13).

Jubelen skyldtes beretningen om det arbejde, en bestemt indisk præst stod for i Arcotmissionen i Sydindien. Deltagerne i Mandekredsen, Kredsforening nr. 41 i DMS, havde via missionærbreve og -besøg fulgt den unge inder fra hans omvendelse til kristendommen til hans præstearbejde i missionens tjeneste. Deltagerne i mandekredsen levede sig dybt ind i den indiske verden og særligt den unge præsts liv og virke. De havde oplevet et kald til at bringe kristendommen til Indien. Det var lykkedes, og nu var der flere, der sluttede sig til kristendommen i Indien i kraft af den indfødte præsts arbejde.

I sin ph.d.-afhandling taler Henschen om drivkraften i missionsbevægelsen som "empatisk globalisering". ${ }^{8}$ Målet var ganske enkelt, at flere og flere af de mennesker, som Gud og missionsvennerne elskede, måtte komme til at dele missionsvennernes kristne tro i det stigende antal lande i Asien, Mellemøsten og Afrika, hvortil ikke blot DMS, men efterhånden også en halv snes andre folkekirkelige missionsselskaber sendte danske missionærer. Det skete især efter missionens sto-

7. Det eneste større bidrag foreligger i form af et lokalstudium: Anne-Lise Schou, Ydre og Indre Mission $i$ Vendsyssel 1870-1920 (København: Gads Forlag 1987).

8. Daniel Henschen, Kaldets verden. En historie om missionsbevagelsen $i$ Danmark fra 1890 til 1950 (Syddansk Universitet: Upubliceret ph.d.-afhandling 2017, 283). 
re gennembrud i 1890'ernes entreprenørtid, hvor også så meget andet blev sat i værk i Danmark.

Historien om missionssynet, arbejdsformerne og DMS' organisering og ledelse som en del af dansk kirkehistorie er hovedemner i det nævnte værk af Harald Nielsen. Han illustrerer Henschens hovedtese perfekt, når han i forordet til sit værk fortæller, hvordan han som dreng i 1950'erne i Sæby med spænding ventede på, at Dansk Missionsblad skulle komme med posten hver anden uge: “... jeg var sulten på verden, og i Dansk Missionsblad kom verden til mig" (Nielsen 2019 I, 13). Missionsbevægelsen var, som én af Henschens hovedteser lyder, en hovedbidragyder til danskernes kontakt med den store verden uden for Europa i perioden 1890-1960.

\section{Folkelig succes og politisk kritik}

På sit højdepunkt i første del af det 20. århundrede havde missionsbevægelsen 100.000 medlemmer organiseret i kredse som mandskredsen i Viborg. I alt nåede bevægelsen ifølge Henschens undersøgelser ud med sine beretninger fra de fremmedes verden til omkring $15 \%$ af den danske befolkning. Ikke blot kom selskabernes blade i store oplag, det gjorde også deres bøger, som bidrog med det stærkeste samlede bidrag til danskernes kendskab til, hvad man efter kolonitiden kaldte u-landene. Det var i øvrigt vækkelserne og ydre missionsvennerne, der opfandt de læsekredse med cirkulerende bøger, der, når de var læst af alle, blev solgt på auktion blandt kredsenes medlemmer, og som blev forløberne for folkebibliotekerne i Danmark. Hertil kom offentlige møder med missionærer på hjemmeophold og efterhånden også med markante repræsentanter for de nye kirker. Den bredeste kontakt opnåede man med store missionsudstillinger, der på mange måder foregreb de events, vi i dag kender i form af udstillingsmesser og interaktive oplevelsesrum i moderne museer. Missionærerne havde hjembragt masser af eksotiske genstande, lokale klædedragter foruden billeder og film, så danskerne kunne få kulturoplevelser, som ingen andre, heller ikke museerne, dengang kunne matche. Overalt var missionærerne nøglepersonerne. I 1920 var der ca. 200 udsendt af folkekirkelige missionsselskaber (Henschen 2019, 146f.).

Allerede fra den første begyndelse med Lyngbypræsten Bone Falch Rønnes grundlæggelse af DMS i 1821 var kritikken mod missionsindsatsen hård. Fyns biskop Frederik Plum, klagede således til Danske Kancelli over Rønnes missionsagitation: 
Da tænkende Mænd har overbevist sig om, at der ved det hele evangeliske Missionsvæsen udrettes lidet eller intet til Jesu sande Læres og Evangeliets Udbredelse - da synes det upassende, at Danmark med sine indskrænkede Midler til at forskaffe Skolelærere for sine indfødte tilstrækkeligt Udkomme, skal betale Lærere i andre Verdensdele for at undervise og døbe Mennesker, som førend de kaldtes Kristne, var Bærmen af Hedninger, og efter at de ophørte at kaldes Hedninger, blev Bundfaldet af Kristne (Henschen 2019, 41). ${ }^{9}$

Morsomt nok var argumentationen omtrent den samme i de kristendomskritiske aviser omkring 1890. Det primære argument var ikke den direkte undsigelse af kristendommen, men det 19. århundredes grundlæggende evolutionistiske tankegang, hvorefter fremmede folkeslag ikke var i stand til at blive ligeså "civiliserede" som europæerne, sådan som missionsvennerne åbenbart troede (Henschen 2019, 82f.). Henschen resumerer kritikken således:

Debatter i Social-Demokraten og Politiken udtrykker en bestemt holdning til mission: Det var en hyklerisk foranstaltning, hvis eneste egentlige formål var at kanalisere penge fra godtroende mennesker ned i præstelommerne. Holdningen knytter oplagt an til en gammel og udbredt modstand i mange dele af samfundet mod statsansatte præster med gode indtægter og de kirkelige institutioner i almindelighed - den kritik havde faktisk også være delt af mange af vækkelsernes medlemmer. Det er altså en kritik, hvor selve missionen fylder meget lidt som praksis; i den udstrækning, de lokale befolkninger i missionslandene optræder i argumentationen, er det for at understrege pointen om, at missionen i sig selv er forkastelig: De blev ikke omvendt, og hvis de alligevel skulle blive det, så var de pågældende individer så moralsk forkastelige, at det kunne være det samme - missionen virkede kort sagt ikke. Det er en holdning, der optræder ret ofte i den socialdemokratiske og radikale presse i årene frem mod århundredeskiftet (Henschen 2019, 123).

Politikens første behandling af emnet fra 25. oktober 1888 havde overskriften "Hvad Missionærerne udretter og hvad det koster". Kritikkens fokus på, hvor mange der blev omvendt, var ofte helt skævt i forhold til missionens virkelighed - og missionsvennernes tankegang og tålmodighed. En islammissionær som Alfred Nielsen, der arbejdede 43 år i arabiske lande, så meget få blive kristne i kraft af sin virksomhed. Til gengæld var han pioner for den form for dialog-

9. Harald Nielsen bringer samme citat med uddybning og kontekstualisering (Nielsen I 2019, 45). 
arbejde mellem kristne og muslimer, som islammissionens arvtager, Danmission, i dag søger at fremme med støtte fra DANIDA's "Arabiske initiativ" og EU. Og Alfred Nielsen var fra de første zionistiske bosættelser i 1930'erne den fremmeste danske fortaler for palæstinensernes sag (Henschen 2019, 201-203; 231 og 248).

\section{Missionsudstillinger og selvkritik}

Efter anden verdenskrig bredte synet for missionens mellemfolkelige betydning sig. Det var et tidens tegn, at den internationale missionsbevægelses fremmeste leder, amerikaneren John R. Mott, fik Nobelprisen i 1946, dog til deling med lederen af Kvindernes internationale liga for Fred og Frihed, englænderen Emily Balch. Den 3. september 1947 kunne de danske missionsudstillingers fællesudvalg slå dørene op for den største udstilling siden 1920'erne. I løbet af fem dage strømmede de besøgende til Aarhushallen, og da udstillingen lukkede, var den med 35.000 besøgende den mest besøgte nogensinde. På åbningsdagen sendte Danmarks Radio 20 minutters dækning af "Danske Missionærers Arbejdsmark. Reportage fra Indien, Kina og Afrika - paa Missionsudstillingen i Aarhushallen". Selv tidligere modstandere var begejstrede: Det socialdemokratiske dagblad Demokraten hyldede udstillingen på forsiden: “... man synes at kunne høre Alverdens Tungemaal summe i den store $\mathrm{Hal}$, naar man vandrer den igennem". Avisen fik nærmest fremstillet udstillingen som en del af det arbejdende folks sag: "Det er en stor og fornøjelig Udstilling, der vidner om, hvor stort et Arbejde mange Mennesker gennem hele deres Liv har gjort langt borte i det Fremmede" (Henschen 2019, 222). Begejstringen for de mange forskellige nationer og det store arbejde " $i$ det Fremmede", drev missionsbevægelsen fremad i de år. Bevægelsen havde støtte i flere samfundslag. Ofte var der tale om et møde mellem periferier, når danskere, der var rekrutteret fra underklassen, kom til at arbejde sammen med fattige og marginaliserede mennesker i de lande, hvor de fik deres virke (Henschen 2019, 56).

Der findes som bekendt nu en omfattende debat om negative og positive sider ved missionsbevægelsens indsats i lande, der som regel var koloniserede af vestlige magter. Sudanmissionens pionermissionær, lægen Niels Brønnum var på det rene med de negative sider ikke blot af det engelske kolonistyre, men også af den kristne mission, sådan som han havde oplevet dem begge i Nigeria. I en bog fra 1955 skriver han: 
Det ville være rart, hvis vi kunne standse her og efterlade det indtryk, at det er den fremmede regering, handelen og industrien, der er skyld i alt dette. Men det kan vi ikke. Den kristne mission må vedkende sig sin medskyld... Det er vor kultur, vor civilisation, vor viden, der bryder ind over Afrika. Vi kan ikke gå ind i Afrika med Kristi evangelium uden samtidig at fremstille os iklædt den kultur og den civilisation. Vi har været med til at lære afrikanerne individualisme, europæisk civilisation og penges værdi at kende - samtidig med at vi forsøgte at lære dem, hvad kristendom er (Henschen 2019, 86).

De danske missionærer kom fra en kultur, der lignede koloniembedsfolkenes. Ofte var de tilmed ganske kontant afhængige af kolonimagten med hensyn til ophold, forsyninger og transport. Der var dog den forskel mellem de to parter, at kolonimagten kunne få sine budskaber igennem ved hjælp af geværer, mens missionærerne måtte tættere på folk, hvis deres budskab skulle have en chance. Derfor kom missionærerne ofte i konflikt med kolonimagten, fordi de studerede og levede sig langt ind i de lokales situation (Henschen 2019, 83ff.).

Der er eksempler på, at missionærerne for hurtigt trak sig ud af et område, så de nye kristne stod alene og meget udsatte tilbage. Der er også eksempler på det modsatte, $\mathrm{fx}$ i den indtil for nyligt ganske uselvstændige Arcot-kirke i Sydindien. DMS' generalsekretær Conrad Rendtorff omtalte missionsselskabets fejltagelser således i sin årsberetning fra 1950: "Man kan ødelægge børn og unge mennesker ved at hjælpe dem for meget $\mathrm{i}$ stedet for at lægge ansvaret over på dem, og man kan måske også komme til at skade en ung kirke ved at hjælpe den for meget" (Nielsen II 2019, 196). Den paternalistiske stil finder vi også i Rendtorffs overvejelser af, om DMS skulle gå ind i arbejdet i Tanzania efter anden verdenskrig, hvor de tyske missionærer var blevet sendt hjem: "Det er et spørgsmål, om det ikke for DMS' stilling herhjemme ville være af betydning før eller senere at få en mission blandt decideret primitive folkeslag, som vi i nogen måde kunne få her...” (Nielsen II 2019, 220). Da DMS-missionærerne, på nær én, der havde kinesisk statsborgerskab, måtte forlade Kina efter revolutionen i 1949, havde DMS ressourcer til et stærkt engagement i Tanzania, der fortsætter den dag i dag. Det var en væsentlig del af baggrunden for, at Tanzania også blev et af DANIDAs prioriterede lande. 


\section{Missionens betydning for ulandsbilledet i Danmark}

Daniel Henschen vil "normalisere" synet på mission og forstår den som en kulturel aktivitet, der har sine paralleller i mange lignende aktiviteter, både før og samtidigt med den kristne mission (Henschen 2019, 9, 16-18). Ved at studere kirke og kristendom som en integreret del af samtidens kultur følger han metoden fra Niels Henrik Gregersens og Carsten Bach-Nielsens trebinds værk om reformationens betydning i dansk kirke og kultur. ${ }^{10}$ Den danske missionsbevægelse beskriver Henschen som et stykke aktiv globalisering, før verden for alvor blev globaliseret efter 1960, hvor en lang række aktører med DANIDA og Mellemfolkeligt Samvirke i spidsen forsøgte at gøre hjælpen til verdens fattigste til en folkesag i Danmark. Missionsbevægelsens rolle som forløber for den sekulære ulandsbevægelse er beskrevet i flere fremstillinger af DANIDA's tidlige historie. Uden missionsbevægelsens indsats havde ulandsstøtten næppe fået så hurtig og stabil en opslutning i Danmark. Blandt de personlige forbindelsesled var professor Hal Koch, der sad i Santalmissionens bestyrelse og arbejdede aktivt for forståelse af ulandshjælpens muligheder. ${ }^{11}$ Hans elev, kirkehistorikeren og Afrikaforskeren Holger Bernt Hansen, var i mange år formand for både ulandsrådet og ulandsstyrelsen og medlem af flere centrale udvalg i DANIDA. ${ }^{12}$ En anden slags sammenhæng ses i, at Kristeligt Folkeparti, hvis medlemmer ofte kom fra missionsbevægelsen, var en sikker støtte for ulandsbistanden, mens partiet var i folketinget 1973-2005.

Henschens bog har to formål. Dels formidler den markante resultater fra ph.d.-afhandlingen fra 2017, hvor han har dokumenteret og analyseret metoderne og dybderne i missionsbevægelsens bidrag til dansk kultur- og verdensforståelse. Dels er det Henschens ambition at fremlægge en monografi, der kan blive stående som en autoritativ introduktion til missionsbevægelsen som globaliseringsbevægelse, før globaliseringen slog igennem overalt efter 1960. Begge formål lykkes fornemt. Henschen kan sit håndværk som kulturhistoriker, og han har ikke holdt sig tilbage med et søge bistand hos kirke- og missionshistorikere og folk med specialiseret viden om missionsbevægelsen.

10. Niels Henrik Gregersen og Carsten Bach-Nielsen (red.), Reformationen i dansk kirke og kultur, Bind I-III (Odense: Syddansk Universitetsforlag 2017).

11. Se fx Hal Koch, "Hjælpen til U-landene og ydre Mission", Santalposten 5 (1961), 83-86; "Betænkning om Hjælp til U-landene”, Santalposten 8 (1961) 158193; Fremtiden formes: U-landshjalp og ydre mission (København: Spektrum 1962). 12. Se fx Holger Bernt Hansen, "Mission, udvikling og u-landshjælp", Kirken Mellem Magterne, red. Carsten Bach-Nielsen m.fl. (København: Eksistensen 2007), 109-130. 
Derfor er det svært at finde nævneværdige fejl og mangler i bogen, hvis resultater udtømmer det perspektiv, forfatteren han anlagt i sine studier. Til overflod er bogen både velskrevet og rigt illustreret med samtidige fotos fra Danmissions nye digitale billedarkiv. 